\title{
Screening and optimization of a nitrate reductase-producing Staphylococcus simulans UV-11 and its application
}

\author{
Mengjie Sun ${ }^{1}\left[\right.$ Xibin Ning ${ }^{1,2,3,4}$
}

Received: 2 November 2020 / Accepted: 18 January 2021 / Published online: 10 February 2021

(c) The Author(s), under exclusive licence to Springer Science+Business Media, LLC part of Springer Nature 2021

\begin{abstract}
A strain of Staphylococcus simulans D14 (S. simulans D14) showed the highest nitrate reductase activity (NRA) of $4.52 \mathrm{mM}$ $\mathrm{NO}_{2}{ }^{-} / \mathrm{mg}$ dry weight by the spectrophotometric method, which was screened from traditional Chinese sausage. When the UV mutagenesis time was $25 \mathrm{~s}$, the positive mutation rate was the highest at 26.60\%. The NRA of the obtained positive mutant UV-11 was $9.21 \mathrm{mM} \mathrm{NO}_{2}{ }^{-} / \mathrm{mg}$ dry weight, and the activity was found to be 1.04-fold higher than that of the original strain S. simulans D14. A Plackett-Burman design (PBD) was employed to screen the significant variables $\mathrm{pH}, \mathrm{KNO}_{3}(\%)$ and incubation time (h), and response surface methodology (RSM) was used to optimize the significant variables using a Box-Behnken design (BBD). The results showed that the NRA of $S$. simulans UV-11 was $15.22 \mathrm{mM} \mathrm{NO}_{2}{ }^{-} / \mathrm{mg}^{-}$dry weight under optimum conditions of $37^{\circ} \mathrm{C}, \mathrm{pH} 6.5$, incubation time $15 \mathrm{~h}, \mathrm{KNO}_{3} 0.045 \%, \mathrm{NaCl} 5 \%, \mathrm{NaNO}_{2} 0.015 \%$, peptone $1 \%$, and D-mannitol $1 \%$, which increased by $65.2 \%$ compared with the unoptimized medium. Natural curing agents (containing $10^{7} \mathrm{CFU} / \mathrm{g}$ S. simulans UV-11 under optimal conditions and $1.40 \%$ celery powder, T2) were added to the cured meat model. $\mathrm{T} 2$ produced significantly lighter and redder signals than the control group (C) and the addition of $150 \mathrm{ppm} \mathrm{NaNO}_{2}$ group (T1). The thiobarbituric acid reactive substance (TBARS) of T2 was $2.30 \mathrm{mg}$ malonaldehyde/ $\mathrm{kg}$ product and residual nitrite of T2 was $7.1 \mathrm{ppm}$ after 14 days of storage,which were lower than those groups of C and T1. Taking into account the results of cured meat models, $S$. simulans UV-11 could be selected as a potential starter culture for the processing of natural meat products.
\end{abstract}

Keywords Nitrite $\cdot$ Nitrate reductase activity $\cdot$ Staphylococcus simulans $\cdot$ UV irradiation $\cdot$ Response surface methodology

Xibin Ning

xbning@shou.edu.cn

Mengjie Sun

2832804937@qq.com

1 College of Food Science and Technology, Shanghai Ocean University, Shanghai 201306, China

2 Shanghai Engineering Research Center of Aquatic-Product Processing \& Preservation, Shanghai 201306, China

3 Laboratory of Quality and Safety Risk Assessment for Aquatic Product on Storage and Preservation (Shanghai), Ministry of Agriculture, Shanghai 201306, China

4 National R\&D Branch Center for Freshwater Aquatic Products Processing Technology (Shanghai), Shanghai 201306, China

\section{Introduction}

As a food additive, the presence of nitrite gives meat products a distinct color and flavor, in addition to preventing the growth of harmful microorganisms. However, nitrite will react with secondary amines to form carcinogenic $\mathrm{N}$-nitrosamines, and the probability of generating nitrosamines will greatly increase when a large amount of nitrite is added at the beginning of processing [1].

Natural meat products refer to the prohibition of adding any artificial or chemical additives during processing, such as nitrate or nitrite. Consumers have formed a strong negative view towards chemical or artificial additives, so there is increasing demand for natural meat products containing plant-based nitrate [2]. The demand of consumers for natural meat products continues to grow rapidly, and natural products with typical meat product characteristics have great market potential [3]. If the typical cured meat characteristics are the ultimate goal, coagulase-negative staphylococci 
(CNS), isolated more frequently from fermented meat products, is the key component [4]. Some CNSs, such as Staphylococcus simulans and Staphylococcus carnosus, are used as starter cultures in the fermentation of meat products [5]. On the one hand, aromatic substances and organic acids are released by the protease and lipase activity of CNS, which play important roles in the formation of the flavor of meat products [6, 7]. In addition, the nitrate reductase of CNS can convert natural nitrate of some vegetables into nitrite, which contributes to the formation of nitrosomyoglobin [4], and the residual nitrite is lower than that of traditional meat products with the direct addition of sodium nitrite [8]. The nitrate concentration of commercial celery powder is as high as $27,500 \mathrm{mg} / \mathrm{kg}$. If $3.60 \mathrm{~g}$ celery powder is added to $1 \mathrm{~kg}$ meat paste, then the nitrate concentration is $100 \mathrm{mg} /$ $\mathrm{kg}$ [9]. Sindelar [10] employed celery powder and starter cultures containing Staphylococcus carnosus to natural meat products. There was no difference between the experimental group with added natural curing agents (comprising a plant-based nitrate and Staphylococcus carnosus) and the control group with added nitrite on the effect of the quality characteristics of ham during the 90 -day storage period. Jin [11] studied the effects of the experimental group with $0.8 \%$ celery powder and the control group with $100 \mathrm{ppm}$ nitrite on the physicochemical traits of sausages after $4{ }^{\circ} \mathrm{C}$ cold storage for 4 weeks. It was concluded that the residual nitrite in the experimental group was $17 \mathrm{ppm}$, which was lower than that of the control group ( $29 \mathrm{ppm})$.

The color of natural meat products is an important reference factor that affects consumer purchases [11]. In nitratecured sausages, strains with higher nitrate reductase activity (NRA) are essential to ensure optimal color formation in the initial fermentation stage [12]. The distinctive color of natural meat products is usually based on the NRA of catalase-positive Staphylococci [13]. Cured color stability is produced in meat products owing to the influence of NRA on the formation of nitrosomyoglobin [14]. Bosse [15] used two strains of Staphylococcus carnosus with different NRA as starter cultures to explore the effect on the color formation of curing raw ham. Cured ham inoculated with the strain with high NRA had lower oxidation effects, and a cured brightred color was observed. The significant difference between batches of Staphylococcus carnosus confirmed that NRA was the key point in color formation. The color of natural meat products can be measured by the L* (lightness), a* (redness), and $b^{*}$ (yellowness) values of the colorimeter or the spectral analysis of meat pigment [16]. In the past decade, extensive research has been approved on the effect of CNS on the color formation of fermented meat products. However, very little attention has been given to the increase in enzyme activity and enzyme-producing conditions of the CNS, and the response surface method (RSM) has been utilized to determine the factors that affect enzyme activity and explore how to interact with factors to maximize NRA.

The objective of this work was to screen strains producing nitrate reductase from traditional Chinese sausages, to induce the original strains with higher enzyme activity by ultraviolet (UV) irradiation and to optimize medium components and fermentation physical variables by RSM. Natural curing agents containing selected strains and celery powder were applied to the cured meat model system to study the color formation and antioxidant capacity, which is of great significance to the development of natural meat products.

\section{Materials and methods}

\section{Materials, chemicals and media}

Traditional Chinese sausages were obtained from the agribusiness supermarket of Shanghai. Celery power was purchased from Jiangsu Huashuo Food Co., Ltd. (Jiangsu, P. R. China). Tryptose soya agar (TSA) media and tryptose soya broth (TSB) media were provided by Shanghai Nuodi Biotechnology Co., Ltd. (Shanghai, P. R. China). The DNA extraction kit was purchased from Tiangen Biochemical Technology Co., Ltd (Beijing, P. R. China). All reagents were of analytical grade and purchased from Sinopharm Chemical Reagent Co., Ltd. (Shanghai, P. R. China).

\section{Screening and identification of bacterial strains}

Strains were isolated from fifteen traditional Chinese sausages by mannitol salt agar (MSA) medium. The selected catalase-positive strains were inoculated on a spot on the surface of MSA medium supplemented with $0.1 \% \mathrm{KNO}_{3}$ for preliminary screening [17]. The spectrophotometric rescreening method of NRA was measured as described by Miralles et al. [18].

According to Berger's Systematic Bacteriology Manual [19] and the Common Bacterial System Identification Manual [20], the screened original strains with high NRA were identified based on colony morphology, biochemical characteristics and 16S rDNA sequencing.

\section{UV irradiation and screening}

\section{Preparation of bacterial suspension}

The identified strain was removed from the $-80{ }^{\circ} \mathrm{C}$ refrigerator and inoculated on a slant to activate the strain. The strain was inoculated into MSA liquid medium from the slant. Five milliliters of the bacterial cultures were harvested by centrifugation at $5000 \mathrm{rpm}$ for $10 \mathrm{~min}$ during the exponential 
growth phase, and the supernatant was discarded. After adding $0.85 \%$ sterile normal saline (NS) for washing twice, bacterial cells were resuspended in NS supplemented with glass beads for shaking for $10 \mathrm{~min}$. The bacterial suspension concentration was adjusted to approximately $10^{8} \mathrm{CFU} / \mathrm{mL}$.

\section{UV irradiation and bacterial screening}

The $5 \mathrm{~mL}$ bacterial suspension at $10^{8} \mathrm{CFU} / \mathrm{mL}$ and sterile magnetic stir bars were distributed in $90 \mathrm{~mm}$ petri-plates, which were placed on the magnetic stirrer. Mutations were induced using a UV lamp at $253.7 \mathrm{~nm}$. The distance between the bacterial suspension surface of petri plates and the UV lamp was adjusted to $30 \mathrm{~cm}$ [21]. The exposure time was varied from 0 to $60 \mathrm{~s}$ at $5 \mathrm{~s}$ intervals. The bacterial suspensions under different exposure times were diluted using $0.85 \%$ sterile NS up to $10^{-1}, 10^{-2}, 10^{-3}, 10^{-4}, 10^{-5}$, and $10^{-6}$, and each gradient was set up in two parallels. A $0.1 \mathrm{~mL}$ bacterial suspension was inoculated on the TSA medium by a spreading plate. The irradiated petri plates were wrapped with black paper and incubated for $24-36 \mathrm{~h}$ at $37^{\circ} \mathrm{C}$ to count the colonies and calculate the lethality rate. Clearly visible mutant colonies were transferred to MSA liquid medium. The NRA of the strains was measured to calculate the positive mutation rate and select the optimal mutant. The lethality rate and positive mutation rate (the NRA of positive mutant strains was increased by more than $20 \%$ compared with the original strain) were calculated according to the following formulas:

Lethality rate $(\%)=\frac{\text { Colonoy number before irradiation }}{\text { Colony number of irradiation }} \times 100 \%$

Positive mutation rate $(\%)=\frac{\text { Number of positive } m u \tan t \text { colonies }}{\text { Total number of } m u \tan t s} \times 100 \%$

\section{Statistical optimization}

\section{Plackett-Burman design (PBD)}

The Plackett-Burman design is used to study the interaction between variables and their influence on NRA (positive or negative effect), which also contributes to minimizing the probability of error and screens out the most influential independent factors [22]. On the basis of the single factor experiment, 10 independent variables ( 8 factors and 2 dummy variables to check the experimental error) were selected, and the NRA was taken as the response value according to the PBD experiment. Each variable was represented at two levels of low $(-1)$ and high $(+1)$. The coded values of the factors and levels of the PBD experiment are listed in Table 1, and data analysis was performed using Minitab 17.0 software.
Table 1 Process variables used in the Plackett-Burman design

\begin{tabular}{llll}
\hline Variable code & Variable name & \multicolumn{2}{l}{ Level } \\
\cline { 3 - 4 } & & Low level (-1) & High level (+1) \\
\hline $\mathrm{A}$ & Temperature ( $\left.{ }^{\circ} \mathrm{C}\right)$ & 37 & 44 \\
$\mathrm{~B}$ & Incubation time (h) & 12 & 18 \\
$\mathrm{C}$ & $\mathrm{pH}$ & 5 & 7 \\
$\mathrm{D}$ & $\mathrm{NaCl}(\%)$ & 5 & 7 \\
$\mathrm{E}$ & $\mathrm{NaNO}_{2}(\%)$ & 0.015 & 0.02 \\
$\mathrm{~F}$ & $\mathrm{KNO}_{3}(\%)$ & 0.03 & 0.045 \\
$\mathrm{~J}$ & $\mathrm{Peptone} \mathrm{( \% )}_{\mathrm{H}}$ & 1.0 & 1.5 \\
$\mathrm{H}$ & D-mannitol (\%) & 1.0 & 1.5 \\
$\mathrm{I}$ & Dummy variable 1 & -1 & 1 \\
$\mathrm{~J}$ & Dummy variable 2 & -1 & 1 \\
\hline
\end{tabular}

Table 2 Factors and levels of response surface experiments

\begin{tabular}{lllll}
\hline Variable code & Variable name & \multicolumn{2}{l}{ Levels } & \\
\cline { 3 - 5 } & & -1 & 0 & +1 \\
\hline $\mathrm{A}$ & $\mathrm{pH}$ & 6.0 & 7.0 & 7.5 \\
$\mathrm{~B}$ & $\mathrm{KNO}_{3}(\%)$ & 0.03 & 0.045 & 0.06 \\
$\mathrm{C}$ & Incubation time (h) & 12 & 15 & 18 \\
\hline
\end{tabular}

\section{Optimization of NRA production by the Box-Behnken design (BBD)}

The single method has severe flaws with regard to ignoring complete interactions between physical and medium component variables. RSM was widely employed to analyze potential relationships between independent variables, as well as to quantify the interaction between significant variables in pursuit of finding the optimal conditions and obtaining the maximum or minimum of the expected solution [23]. The production was optimized with RSM-BBD for significant variables $\mathrm{pH}(\mathrm{A}), \mathrm{KNO}_{3}(\mathrm{~B})$, and incubation time (C) obtained from PBD, and NRA was treated as the response value. The three factors and corresponding three levels in the central combination plan are shown in Table 2 for a total number of 17 random experimental runs. The data were analyzed with Design-Expert 8.0.6 software to find the optimal experimental parameters to obtain the optimal response value.

\section{Application}

\section{Preparation of starter cultures}

UV-11 optimized by RMS was inoculated in $10 \mathrm{~mL}$ MSA liquid medium, which was cultured with shaking at $37^{\circ} \mathrm{C}$ for $15 \mathrm{~h}$. The culture was centrifuged, and the cellular pellet was resuspended in $10 \mathrm{~mL}$ physiological saline to an $\mathrm{OD}_{600}=0$. 
Table 3 The basic formulation of cured meat models

\begin{tabular}{llll}
\hline Ingredients $(\%)$ & \multicolumn{3}{l}{ Type of cured meat model } \\
\cline { 2 - 4 } & $\mathrm{C}$ & $\mathrm{T} 1$ & $\mathrm{~T} 2$ \\
\hline Lean pork & 70 & 70 & 70 \\
Pork backfat & 26.5 & 26.5 & 25.1 \\
Freeze-dried celery & - & - & 1.4 \\
$\mathrm{NaCl}$ & 2.7 & 2.7 & 2.7 \\
Black pepper & 0.2 & 0.2 & 0.2 \\
Glucose & 0.6 & 0.6 & 0.6 \\
$\mathrm{NaNO}_{2}$ & - & 0.015 & - \\
\hline
\end{tabular}

227. The concentration of the bacterial strain was adjusted to approximately $10^{8} \mathrm{CFU} / \mathrm{mL}$.

\section{Preparation of cured meat model}

To evaluate the effect of UV-11 in the cured meat models, three batches of cured meat model formulations were prepared: control group (C); 150 ppm $\mathrm{NaNO}_{2}$ group (T1); natural curing agent that was composed of celery powder $1.4 \%$ (containing 10,682 ppm nitrate) and UV-11 (10 $\mathrm{CFU} / \mathrm{g}$ ) group (T2). The specific formula is shown in Table 3 . After crushing the pork, various auxiliary materials were added and stirred at high speed for $3 \mathrm{~min}$ in a food processor. The aliquot was exposed to a UV lamp for $2 \mathrm{~h}$ for sterilization. The culture of UV-11 was incubated in meat mixtures, and the meat sample of each group was filled into casings. Three cured meat models with vacuum packaging were placed into a constant temperature incubator at $37^{\circ} \mathrm{C}$ for $24 \mathrm{~h}$ and then placed into a constant temperature and humidity incubator. The temperature on the first day was set to $25^{\circ} \mathrm{C}$ and remained at that temperature for five days. After five days, the temperature was reduced by $1{ }^{\circ} \mathrm{C}$ every day to $18{ }^{\circ} \mathrm{C}$. The humidity was set to $95 \%$ on the first three days, $85 \%$ on the 4 th day, $80 \%$ on the 5 th day and $75 \%$ at the end. The color, Aw, thiobarbituric acid-reactive substance (TBARS), residual nitrite and other indicators were measured at $0 \mathrm{~h}$, 24 h, 48 h, 72 h, and 14 days of fermentation [24, 25].

\section{Statistical analysis}

All observations composing the experiment were included in the statistical analysis. All tests were performed in triplicate. Analysis of variance (ANOVA) was conducted separately for the dependent variables using SPSS. Differences were considered significant at $\mathrm{p}<0.05$. Origin was applied to design single-factor experimental data analysis and graphing. Minitab 17 was used to design the PBD and analyze the experimental data. The response surface analysis of the interaction among significant variables was conducted by Design-Expert 8. 0.6 software using BBD.

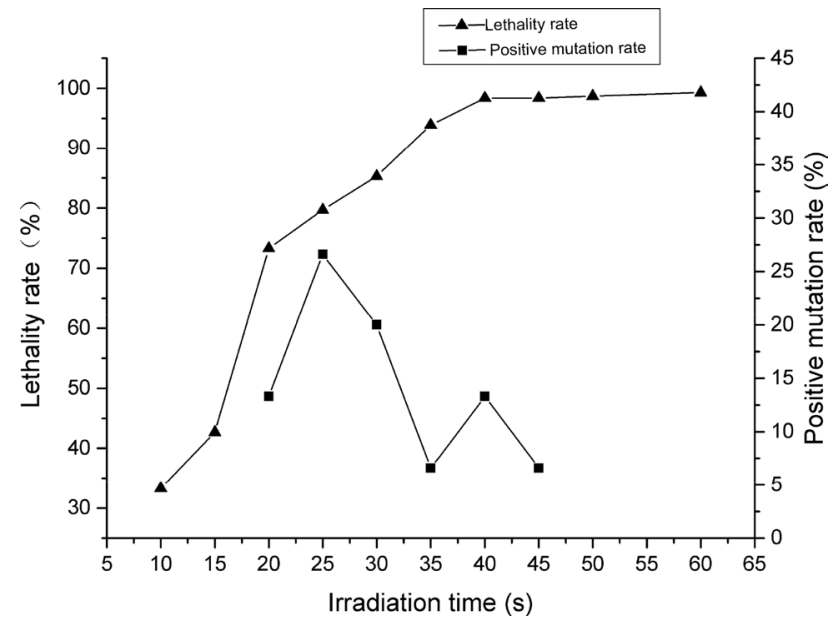

Fig. 1 Effect of UV irradiation on the lethality rate and positive mutation rate of $S$. simulans D14

\section{Results and discussion}

\section{Screening and identification of bacterial strains}

Nitrate reductase is a membrane-bound enzyme involved in the preservation of respiratory energy, and its synthesis is induced by nitrate and nitrite to varying degrees and is inhibited by oxygen [26]. Therefore, MSA basic medium supplemented with $\mathrm{KNO}_{3}$ and $\mathrm{NaNO}_{2}$ contributed to producing higher NRA. The 198 catalase-positive bacterial strains selected from sausages were preliminarily screened by the agar plate method, and 108 strains producing nitrate reductase were used for further spectrophotometric rescreening. According to the determination results of the spectrophotometry method, the NAR of strain D14 was the highest for $4.52 \mathrm{mM} \mathrm{NO}_{2}^{-} / \mathrm{mg}$ dry weight among the rescreened strains for further research. In accordance with the morphological, physiological and biochemical characteristics, D14 was determined to belong to Staphylococcus. Based on $16 \mathrm{~S}$ rDNA molecular biological identification, strain D14 was further identified as Staphylococcus simulans [27], and its gene sequence was deposited in the GenBank database with accession number MT568571.

\section{UV irradiation and screening}

It was obvious that the original strain S. simulans D14 was susceptible to UV treatment. As the exposure time increased, the lethality rate gradually increased (Fig. 1). The lethality rate of treatment for $10 \mathrm{~s}$ was $33.3 \%$, yet the fatality rate was $79.7 \%$ at $25 \mathrm{~s}$, which would reach $85.3 \%$ at $30 \mathrm{~s}$. The longer the bacteria were exposed to UV irradiation, the greater the devastating effects to the bacterial DNA. The study shows that the positive mutation rate was higher when the lethality 
Table 4 Factors, levels and significance analysis of the Plackett-Burman design

\begin{tabular}{|c|c|c|c|c|c|c|}
\hline \multirow[t]{2}{*}{ Variable code } & \multirow[t]{2}{*}{ Variable name } & \multicolumn{2}{|l|}{ Level } & \multirow[t]{2}{*}{$\mathrm{T}$ value } & \multirow[t]{2}{*}{$P$ value } & \multirow{2}{*}{$\begin{array}{l}\text { Impor- } \\
\text { tance } \\
\text { ranking }\end{array}$} \\
\hline & & Low $(-1)$ & $\operatorname{High}(+1)$ & & & \\
\hline A & Temperature $\left({ }^{\circ} \mathrm{C}\right)$ & 37 & 44 & 20.44 & 0.031 & 4 \\
\hline B & Incubation time $(\mathrm{h})$ & 12 & 18 & 21.64 & 0.029 & 3 \\
\hline $\mathrm{C}$ & $\mathrm{pH}$ & 5 & 7 & -30.30 & 0.021 & 1 \\
\hline $\mathrm{D}$ & $\mathrm{NaCl}(\%)$ & 5 & 7 & -13.88 & 0.046 & 7 \\
\hline $\mathrm{E}$ & $\mathrm{NaNO}_{2}(\%)$ & 0.015 & 0.02 & -6.84 & 0.092 & 8 \\
\hline $\mathrm{F}$ & $\mathrm{KNO}_{3}(\%)$ & 0.03 & 0.045 & -24.71 & 0.026 & 2 \\
\hline G & Peptone (\%) & 1.0 & 1.5 & -18.58 & 0.034 & 5 \\
\hline $\mathrm{H}$ & D-mannitol (\%) & 1.0 & 1.5 & 1.44 & 0.387 & 10 \\
\hline I & Dummy variable 1 & -1 & +1 & -15.84 & 0.040 & 6 \\
\hline $\mathrm{J}$ & Dummy variable 2 & -1 & +1 & -2.96 & 0.207 & 9 \\
\hline
\end{tabular}

rate of UV treatment was between 70 and $80 \%$ [28]. Five irradiation times with lethality rates between 70 and $99 \%$ were selected to determine the positive mutation rate. The results showed that when UV treatment was applied for $25 \mathrm{~s}$, the positive mutant UV-11 was screened out with a relatively high NRA of $9.21 \mathrm{mM} \mathrm{NO}_{2}^{-} / \mathrm{mg}$ dry weight, and the NRA of UV-11 increased by 1.04 fold compared to $S$. simulans D14. The positive mutation rate was the highest at this exposure time $(26.60 \%)$.

\section{Statistical optimization}

\section{Plackett-Burman design results}

Each organism requires its own growth conditions for maximum enzyme activity. The significant variables were selected to perform further study following PBD. Minitab Statistical Software v.17.0 (Minitab Ltd., Coventry, United Kingdom) was used to analyze the main effects of the data in Table 1, and the results are shown in Table 4. The three significant variables were $\mathrm{pH}, \mathrm{KNO}_{3}$ and incubation time by analyzing the $\mathrm{P}$ values of eight variables, and their $\mathrm{P}$ values of $0.021,0.026$ and 0.029 were all less than 0.05 , respectively. The single-factor test results of the significant variables are shown in Fig. 2. The $\mathrm{pH}$ level had a significant influence on the enzyme activity (Fig. 2a). After UV-11 was cultured in MSA liquid medium at $\mathrm{pH}$ 4.5 and $\mathrm{pH} 8.0$ for $18 \mathrm{~h}$, the enzyme activity of UV-11 was relatively low at $5.93 \pm 0.30 \mathrm{mM} \mathrm{NO}_{2}^{-} / \mathrm{mg}$ dry weight and $3.50 \pm 0.18 \mathrm{mM} \mathrm{NO}_{2}^{-} / \mathrm{mg}$ dry weight. This may be because low $\mathrm{pH}$ would inhibit the growth of microorganisms, resulting in a higher nitrate content and lower nitrite content of MSA liquid medium [29]. NRA gradually increased with increasing $\mathrm{pH}$, and it reached its peak value at $\mathrm{pH}$ 6.5. In MSA medium components, the $\mathrm{KNO}_{3}$ concentration had a significant influence on the enzyme activity (Fig. 2b). The enzyme activity first increased and then decreased with increasing $\mathrm{KNO}_{3}$ concentration. When the $\mathrm{KNO}_{3}$ concentration was $0.045 \%$, the enzyme activity reached the highest value. The optimal incubation time of UV-11 was $15 \mathrm{~h}$, on which the enzyme activity was slightly higher than at $18 \mathrm{~h}$ (Fig. 2c), owing to the long incubation time, which may cause a fraction of cells to decline. The bacteria died by autolysis, leading to bacterial volume loss and a decrease in enzyme activity. Furthermore, temperature also played a critical role in microbial growth which was not too high or too low [30], and importance ranking of temperature was the fourth among significant factors in accordance with $P$ values. The main effect diagram of screening various parameters of $S$. simulans UV-11 with PBD is shown in Fig. 3, and significant variables were selected for further BBD research.

\section{RSM-BBD of NRA production by S. simulans UV-11}

Based on the results of the PBD experiment, the RSM-BBD method was used to further analyze the significant variables $\mathrm{pH}(\mathrm{A}), \mathrm{KNO}_{3}$ (B) and incubation time (C) in the pursuit of determining the optimal conditions for S. simulans UV-11 to produce nitrate reductase. The 17 experimental runs generated from Design-Expert 8.0.6 software (Table 5) were conducted in duplicate, and NRA was recorded. ANOVA and significance tests were carried out according to the selected model, and multiple regression fitting $\left(\mathrm{R}^{2}\right)$ was performed using the RSM-BBD experimental results. The polynomial equation in terms of coded factors for RSM is shown below:

$\mathrm{NRA}=-461.337+108.5569 \mathrm{~A}+419.6986 \mathrm{~B}+14.10$ $079 \mathrm{C}+63.98513 \mathrm{AB}-0.23035 \mathrm{AC}-14.0587 \mathrm{BC}-8.16$ $477 \mathrm{~A}^{2}-7446.9 \mathrm{~B}^{2}-0.38435 \mathrm{C}^{2}$.

The ANOVA results of the regression model are summarized in Table 6 . $\mathrm{A}, \mathrm{B}, \mathrm{C}, \mathrm{A}^{2}, \mathrm{~B}^{2}$, and $\mathrm{C}^{2}$ had very significant effects on NRA, yet the rest of the terms were not significant. According to the value of $\mathrm{F}$, whose probability was 42.36 with $\mathrm{P}<0.0001$, the model was significant. The lack of fit 


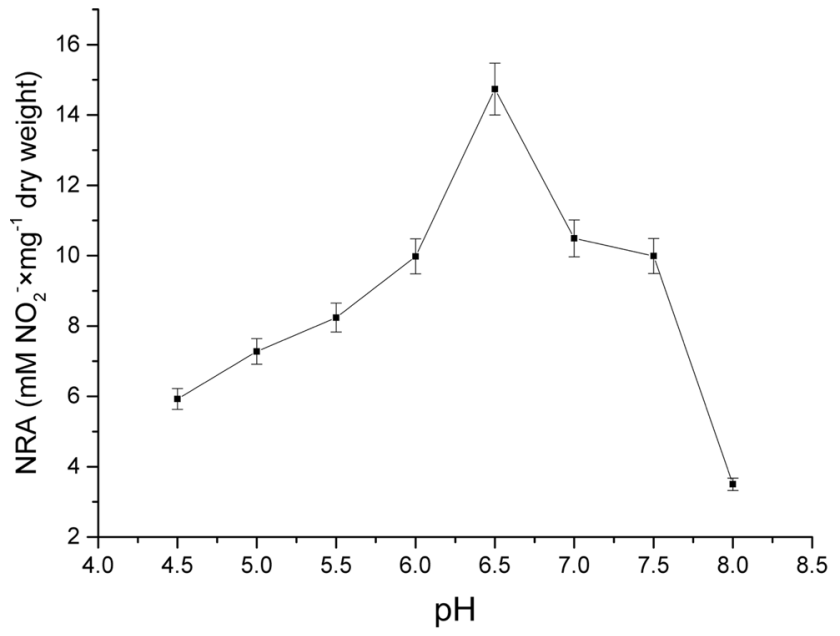

(a)

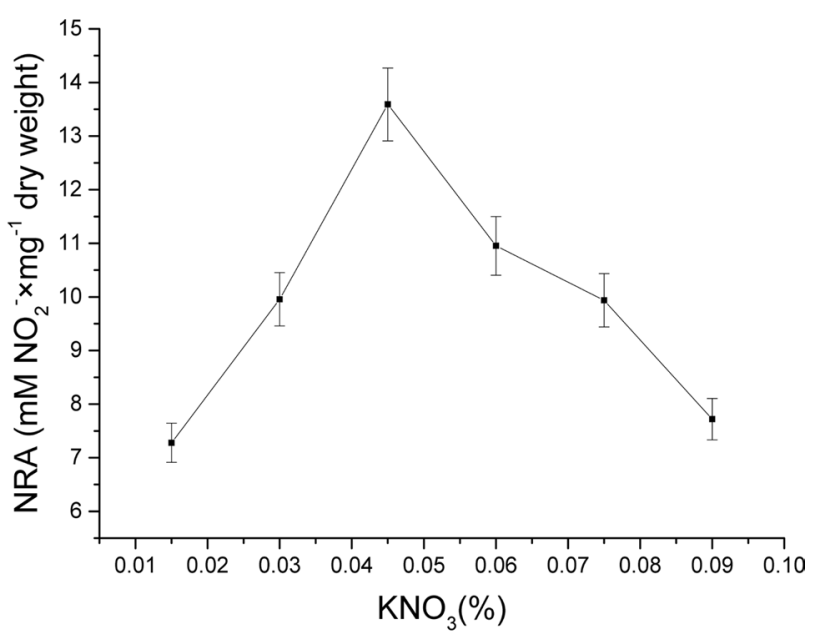

(b)

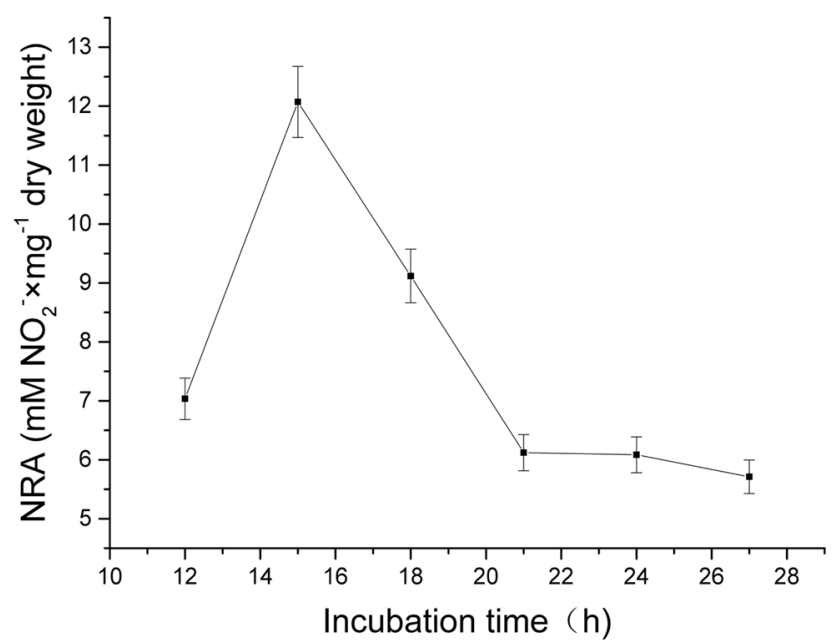

(c)

Fig. 2 Effects of $\mathrm{pH}, \mathrm{KNO}_{3}$ and incubation time on the NRA of UV-11. a Effect of $\mathrm{pH}$ on the NRA of UV-11, $\mathbf{b}$ Effect of KNO 3 on the NRA of UV-11, c Effect of incubation time on the NRA of UV-11

was not significant with a probability value of 0.811 , which showed that the model fit well with the experiment and that a reasonable model was available. The $\mathrm{R}^{2}$ value obtained from RSM analysis was 0.982 , indicating that the linear relationship was obvious and that only $1.8 \%$ of the variation could not be explained by the model. However, the influence of experimental factors on the response value was not simply linear, and the quadratic term also had a great relationship with the response value. The coefficient of correction determination whose probability was 0.959 confirmed that the response surface effect had a high degree of fitting with the experiment, so the regression equation can be used to analyze and predict the test results. The coefficient of variation with a probability of $4.76 \%$ indicated that the model equation can better reflect the real experimental value, and this model can be used to analyze the change in the response value.

\section{Three-dimensional (3D) plots and contour analysis of the response surface}

The interaction analysis of the RSM among independent variables was conducted by Design-Expert 8.6.0 software. The steepness of the 3D stereogram and the contour shape can reflect the strength of the interaction of factors. The steeper the curve was, the more significant the influence was, while the smoother the curve was, the smaller the influence was. The contour line can directly reflect the significant degree of interaction between two variables. The contour lines were elliptic, indicating that there was an obvious interaction 


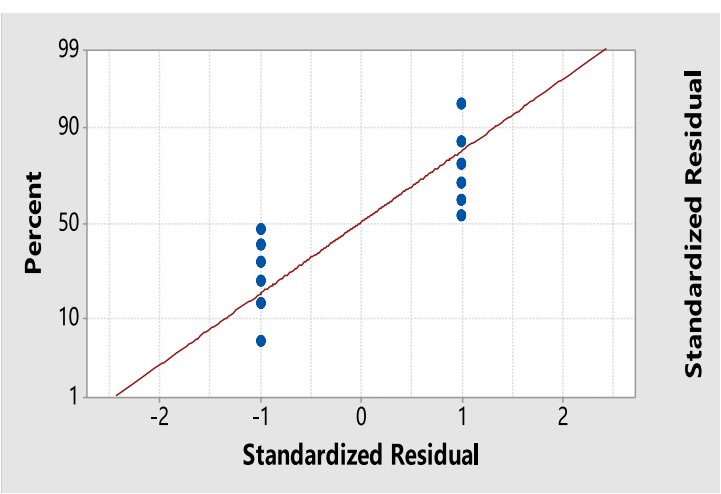

(a)

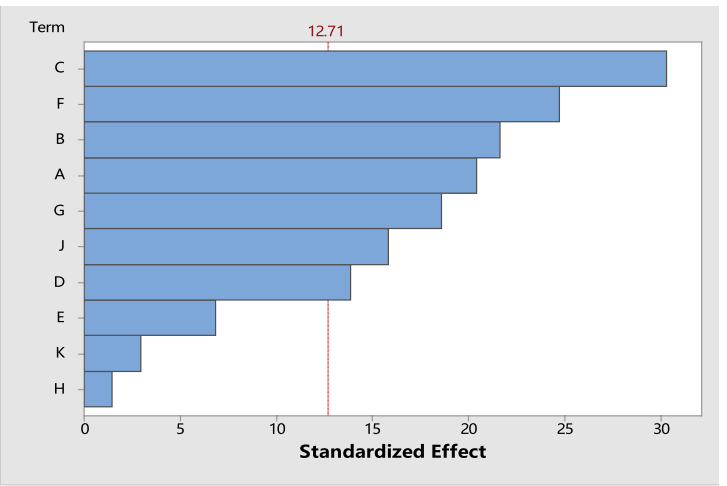

(b)

Fig. 3 Main effect of variables on NRA of UV-11. a Normal plot of standardized effects and $\mathbf{b}$ Pareto chart of standard effects

Table 5 Design and results of the Box-Behnken design

\begin{tabular}{lllll}
\hline Run & \multicolumn{2}{l}{ Independent variables } & $\begin{array}{l}\mathrm{NRA} \\
(\mathrm{mM}\end{array}$ \\
\cline { 2 - 4 } & $\mathrm{A}: \mathrm{pH}$ & $\mathrm{B}: \mathrm{KNO}_{3}(\%)$ & $\begin{array}{l}\mathrm{C}: \text { Incubation } \\
\text { time (h) }\end{array}$ & $\begin{array}{l}\mathrm{NO}_{2}{ }^{-} \times \mathrm{mg}^{-1} \\
\text { dry weight) }\end{array}$ \\
\hline 1 & 6 & 0.03 & 15 & 11.17187 \\
2 & 7 & 0.03 & 15 & 12.28448 \\
3 & 6 & 0.06 & 15 & 9.176118 \\
4 & 7 & 0.06 & 15 & 12.20828 \\
5 & 6 & 0.045 & 12 & 6.854316 \\
6 & 7 & 0.045 & 12 & 9.15082 \\
7 & 6 & 0.045 & 18 & 10.39333 \\
8 & 7 & 0.045 & 18 & 11.30776 \\
9 & 6.5 & 0.03 & 12 & 8.78885 \\
10 & 6.5 & 0.06 & 12 & 8.360128 \\
11 & 6.5 & 0.03 & 18 & 12.48955 \\
12 & 6.5 & 0.06 & 18 & 9.530262 \\
13 & 6.5 & 0.045 & 15 & 13.96889 \\
14 & 6.5 & 0.045 & 15 & 15.58522 \\
15 & 6.5 & 0.045 & 15 & 14.62132 \\
16 & 6.5 & 0.045 & 15 & 15.42814 \\
17 & 6.5 & 0.045 & 15 & 15.0311 \\
\hline & & & & \\
\hline
\end{tabular}

between the two factors, while the contour lines tended to be round, indicating that the interaction between the two factors was not significant [31].

From 3D plots and contour graphs of the response surface in Fig. 4, enzyme activity first increased and then decreased, indicating that enzyme activity had a maximum value within the appropriately selected range. The maximum NRA in the selected range was not only the highest point of the response surface but also the center point of the minimum contour ellipse. As seen from the contour lines and 3D plots of $a, b$, c, $\mathrm{d}$, e and $\mathrm{f}$ in Fig. 4, the interaction of $\mathrm{pH}$ and $\mathrm{KNO}_{3}, \mathrm{pH}$ and incubation time, and incubation time and $\mathrm{pH}$ showed a slightly flattened curvature, indicating that the interaction between the two independent variables was not significant.

The model predicted that the optimum NRA value would be obtained at $\mathrm{KNO}_{3} 0.042 \%$ and an incubation time of $15.61 \mathrm{~h}$. In addition, the NRA was also affected by the incubation temperature of $37{ }^{\circ} \mathrm{C}, \mathrm{NaNO}_{2} 0.015 \%, \mathrm{NaCl}$ $5 \%$, peptone $1 \%$ and D-mannitol $1 \%$, and $\mathrm{pH} 6.5$, and the value should be $15.22 \mathrm{mM} \mathrm{NO}_{2}{ }^{-} / \mathrm{mg}$ dry weight under the optimal conditions. The enzyme activity was increased by $65.20 \%$ compared to unoptimized medium. Using these conditions in a further independent assay, the NAR obtained was $15.87 \pm 0.32 \mathrm{mM} \mathrm{NO}_{2}{ }^{-} / \mathrm{mg}$ dry weight. The predicted value was basically consistent with the actual value, which proved the validity of the model and indicated that the optimal conditions obtained by RSM optimization were accurate and reliable.

\section{Evaluation of color formation, antioxidant capacity and physicochemical properties}

As shown in Table 7, the $\mathrm{L}^{*}$ values of $\mathrm{T} 1$ and $\mathrm{T} 2$ were not significantly different from that of $\mathrm{C}$ at incubation time $24 \mathrm{~h}$. However, with the extension of incubation time, the $\mathrm{L}^{*}$ values of $\mathrm{T} 1$ and $\mathrm{T} 2$ were remarkably higher than that of $\mathrm{C}$ at $48 \mathrm{~h}$ and $72 \mathrm{~h}$, which may be due to the direct addition of $\mathrm{NaNO}_{2}$ in $\mathrm{T} 1$ and indirect transformation in $\mathrm{T} 2$. The $\mathrm{a} *$ and $\mathrm{b} *$ values of $\mathrm{T} 2$ were both higher than those of $\mathrm{T} 1$ in different incubation periods, which further indicated that UV-11 with high NRA played an important role in the formation of color at the initial stage of fermentation. After 14 days of storage, the effects of UV-11 on the antioxidant capacity and physicochemical properties of the cured meat models are shown in Table 8 . The Aw values of the cured meat models after fermentation for $0 \mathrm{~h}$ and after 14 days of storage both decreased to different degrees. When the Aw value was close to 0.86 , the cured meat model was considered edible [32]. 
Table 6 ANOVA of the regression model

\begin{tabular}{lcrcrrl}
\hline Source & Sum of squares & df & Mean square & F value & p-value & \\
\hline Model & 115.3223 & 9 & 12.81359 & 42.36391 & $<0.0001$ & Significant \\
A-pH & 6.763287 & 1 & 6.763287 & 22.36058 & 0.0021 & \\
B-KNO $_{3}$ & 3.726412 & 1 & 3.726412 & 12.32015 & 0.0099 & \\
C- Incubation time & 13.95714 & 1 & 13.95714 & 46.14469 & 0.0003 & \\
$\mathrm{AB}$ & 0.921172 & 1 & 0.921172 & 3.045551 & 0.1245 & \\
$\mathrm{AC}$ & 0.477536 & 1 & 0.477536 & 1.578816 & 0.2492 & \\
$\mathrm{BC}$ & 1.600946 & 1 & 1.600946 & 5.293 & 0.0549 & \\
$\mathrm{~A}^{2}$ & 17.54304 & 1 & 17.54304 & 58.00027 & 0.0001 & \\
$\mathrm{~B}^{2}$ & 11.82095 & 1 & 11.82095 & 39.08207 & 0.0004 & \\
$\mathrm{C}^{2}$ & 50.38296 & 1 & 50.38296 & 166.5746 & $<0.0001$ & \\
Residual & 2.117253 & 7 & 0.302465 & & & \\
Lack of fit & 0.41061 & 3 & 0.13687 & 0.320794 & 0.8113 & Not significant \\
Pure error & 1.706643 & 4 & 0.426661 & & & \\
Cor total & 117.4396 & 16 & & & & \\
\hline
\end{tabular}

After 14 days of storage, the content of nitrite in T2 was lower than that in $\mathrm{T} 1$, and the a *value of $\mathrm{T} 2$ was higher than that of $\mathrm{T} 1$, indicating that natural curing agent added in the cured meat model could not only effectively reduce the residual nitrite but also retain the color stability of the cured meat model. The TBARS differences between T1 and T2 were not significant, yet the TBARS value of group $C$ was higher than that of T1 and T2. The degree of lipid oxidation was higher than in the other two groups. The $\mathrm{L}^{*}$ and $\mathrm{a}^{*}$ values of the cured meat models all had a certain lower degree after 14 days of storage. This result may be explained by the fact that lipid oxidation in meat products led to a deeper color. This was consistent with the experimental results of Jin [11]. The sequence of nitrite reactions related to the color formation of cured meat may also have a strong antioxidant effect in cured meat, and the nitroso compounds formed may have antioxidant properties. The relationship between color formation and antioxidant activity may depend on the same initial reaction of nitrites, which form the nitric oxide of cured meat color [33].

\section{Conclusion}

The color of natural meat products is usually based on NRA of CNS, with emphasis on how to improve enzyme activity in this paper. A total of 108 strains with NRA were screened from traditional Chinese sausage, and strain D14 showed the highest NAR for $4.52 \mathrm{mM} \mathrm{NO}_{2}{ }^{-} / \mathrm{mg}$ dry weight among the rescreened strains by the spectrophotometric method. Strain D14 was further identified as
Staphylococcus simulans based on its colony morphology, biochemical tests and 16S rDNA gene sequencing. The positive mutation rate of $S$. simulans D14 was the highest when the UV irradiation time was $25 \mathrm{~s}$. The positive mutant UV-11 with an enzyme activity of $9.21 \mathrm{mM}$ $\mathrm{NO}_{2}{ }^{-} / \mathrm{mg}$ dry weight was obtained, and the enzyme activity was increased by 1.04-fold compared with D14. On the basis of a single factor, PBD was used to select the three most influential independent variables, $\mathrm{pH}, \mathrm{KNO}_{3}$ and incubation time. RSM-BBD experimental design was employed to optimize the conditions of significant variables affecting the NRA. The optimal conditions for nitrate reductase production by $S$. simulans UV-11 using different physical and chemical parameters were found to be $37{ }^{\circ} \mathrm{C}$, pH 6.5, incubation time $15 \mathrm{~h}, \mathrm{KNO}_{3} 0.045 \%, \mathrm{NaCl} 5 \%$, $\mathrm{NaNO}_{2} 0.015 \%$, peptone $1 \%$, and $\mathrm{D}-$ mannitol $1 \%$ in the MSA lipid medium. Enzyme activity reached $15.22 \mathrm{mM}$ $\mathrm{NO}_{2}{ }^{-} / \mathrm{mg}$ dry weight, which increased by $65.2 \%$ compared with the unoptimized medium. When celery powder and UV-11 under optimal incubation conditions (T2) as a natural cured agent were added to the cured meat model, T2 produced significantly lighter and redder compared to the control group (C) and the addition of 150 ppm $\mathrm{NaNO}_{2}$ group (T1). In addition, the TBARS and residual nitrite of $\mathrm{T} 2$ were lower than those of $\mathrm{C}$ and $\mathrm{T} 1$. Therefore, this paper provides a theoretical basis for the application of Staphylococcus simulans UV-11 as starter cultures in natural meat products. As the addition of CNS with high NRA to meat products, natural nitrate can be reduced to nitrite, which is the most promising way to introduce natural source nitrite into meat products. 
Fig. 4 Response surface 3D plots and contour graphs showing the interaction effects on the NRA of UV-11 (a)

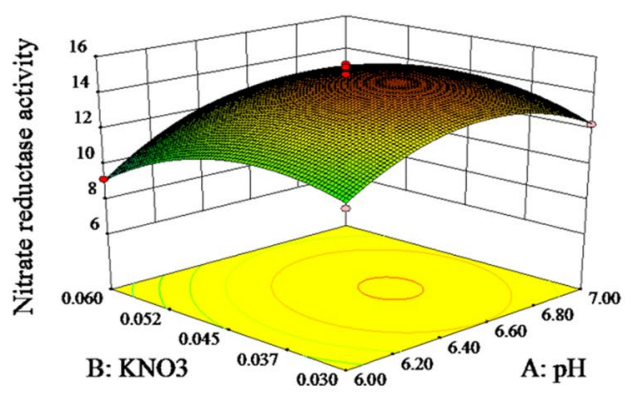

(c)

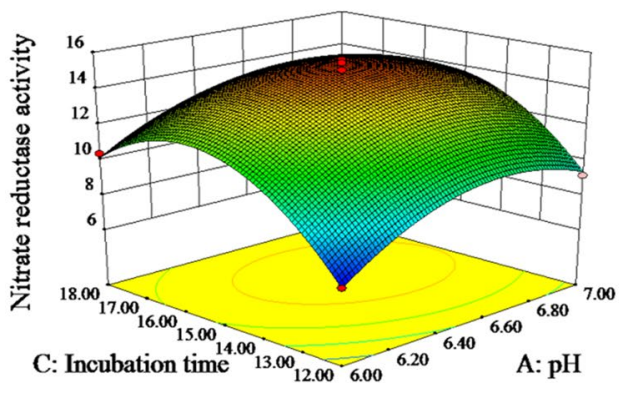

(e)

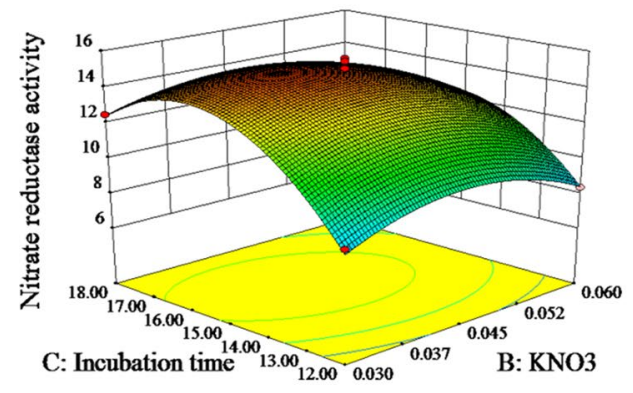

(b)

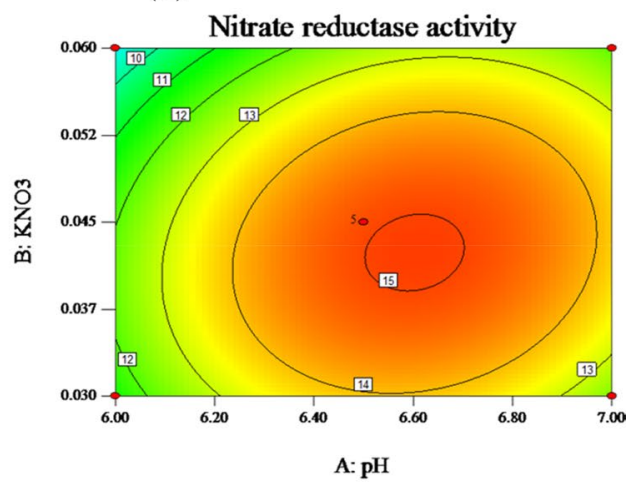

(d)

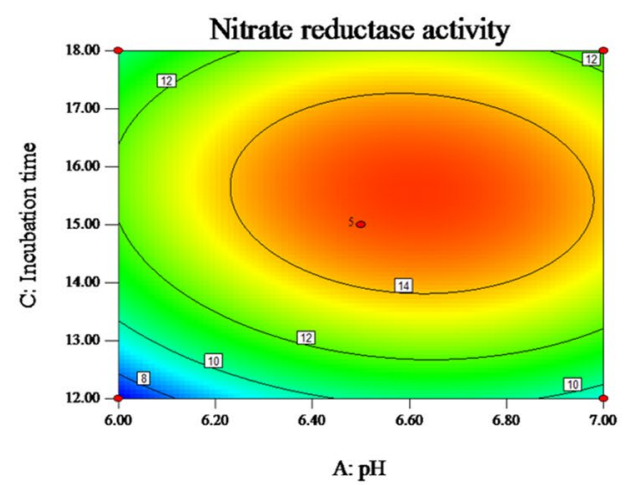

(f)

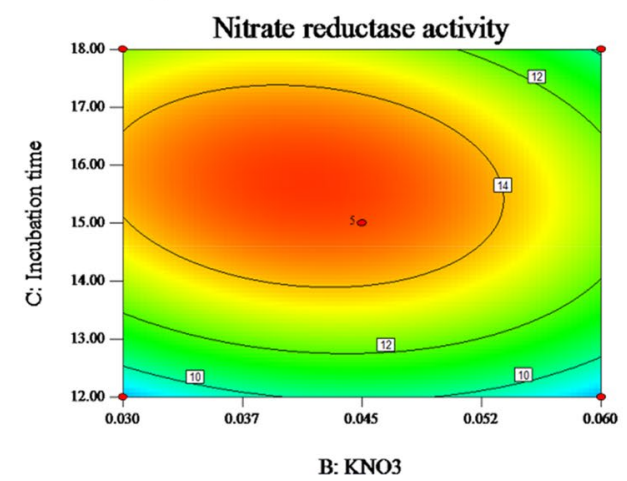

Table 7 Effect of UV-11 on the color formation of cured meat models

\begin{tabular}{lllrrrr}
\hline Technological parameters & Treatments & \multicolumn{2}{l}{ Time } & & & \\
\cline { 3 - 6 } & & $0 \mathrm{~h}$ & $24 \mathrm{~h}$ & $48 \mathrm{~h}$ & $72 \mathrm{~h}$ & 14 days \\
\hline L*(lightness) & $\mathrm{C}$ & 45.75 & 46.45 & 46.76 & 46.60 & 40.33 \\
& $\mathrm{~T} 1$ & 46.78 & 48.49 & 55.13 & 55.20 & 40.78 \\
& $\mathrm{~T} 2$ & 47.59 & 44.39 & 52.09 & 52.13 & 45.94 \\
$\mathrm{~b}$ (yellowness) & $\mathrm{C}$ & 14.35 & 15.35 & 13.90 & 12.37 & 17.47 \\
& $\mathrm{~T} 1$ & 14.81 & 12.97 & 12.29 & 13.15 & 15.45 \\
& $\mathrm{~T} 2$ & 15.44 & 14.70 & 15.19 & 13.54 & 14.42 \\
$\mathrm{a} *$ (redness) & $\mathrm{C}$ & 6.56 & 8.56 & 10.18 & 9.53 & 8.28 \\
& $\mathrm{~T} 1$ & 6.22 & 10.38 & 8.48 & 12.55 & 11.08 \\
& $\mathrm{~T} 2$ & 8.88 & 13.50 & 14.39 & 14.51 & 12.63 \\
\hline
\end{tabular}


Table 8 Evaluation of the antioxidant capacity and physicochemical traits of UV-11 in cured meat models

\begin{tabular}{|c|c|c|c|c|}
\hline \multirow[t]{2}{*}{ Treatments } & \multicolumn{2}{|l|}{ AW } & \multirow{2}{*}{$\begin{array}{l}\text { Residual } \\
\text { nitrite (ppm) }\end{array}$} & \multirow{2}{*}{$\begin{array}{l}\text { TBARS } \\
\text { (mg malonal- } \\
\text { dehyde/kg } \\
\text { product) }\end{array}$} \\
\hline & $0 \mathrm{~h}$ & 14 days & & \\
\hline $\mathrm{C}$ & 0.915 & 0.864 & - & 15.95 \\
\hline $\mathrm{T} 1$ & 0.894 & 0.867 & 11.7 & 2.15 \\
\hline $\mathrm{T} 2$ & 0.919 & 0.868 & 7.1 & 2.30 \\
\hline
\end{tabular}

\section{References}

1. K. Alirezalu, J. Hesari, Z. Nemati, P.E.S. Munekata, F.J. Barba, J.M. Lorenzo, Combined effect of natural antioxidants and antimicrobial compounds during refrigerated storage of nitrite-free frankfurter-type sausage. Food Res. Int. 120, 839-850 (2019). https://doi.org/10.1016/j.foodres.2018.11.048

2. F. Riazi, F. Zeynali, E. Hoseini, H. Behmadi, Effect of dry red grape pomace as a nitrite substitute on the microbiological and physicochemical properties and residual nitrite of dry-cured sausage. Nutr. Food Sci. Res. 3(3), 37-44 (2016). https://doi. org/10.18869/acadpub.nfsr.3.3.37

3. J.G. Sebranek, A.L. Jackson, K.L. Myers, N.A. Lavieri, Beyond celery and starter culture: advances in natural/organic curing processes in the United States. Meat Sci. 92(3), 267-273 (2012). https ://doi.org/10.1016/j.meatsci.2012.03.002

4. G. Landeta, J.A. Curiel, A.V. Carrascosa, R. Munoz, B. De Ias Rivas, Characterization of coagulase-negative staphylococci isolated from Spanish dry cured meat products. Meat Sci. 93(3), 387-396 (2013). https://doi.org/10.1016/j.meatsci.2012.09.019

5. A. Casaburi, G. Blaiotta, G. Mauriello, O. Pepe, F. Villani, Technological activities of Staphylococcus carnosus and Staphylococcus simulans strains isolated from fermented sausages. Meat Sci. 71(4), 643-650 (2005). https://doi.org/10.1016/j.meats ci.2005.05.008

6. A. Casaburi, M.C. Aristoy, S. Cavella, R.D. Monaco, D. Ercolini, F. Toldra, F. Villani, Biochemical and sensory characteristics of traditional fermented sausages of Vallo di Diano (Southern Italy) as affected by the use of starter cultures. Meat Sci. 76(2), 295-307 (2007). https://doi.org/10.1016/j.meatsci.2006.11.011

7. M. Simonova, V. Strompfova, M. Marcinakova, A. Laukova, S. Vesterlund, M.L. Moratalla, Characterization of staphylococcus xylosus and staphylococcus carnosus isolated from Slovak meat products. Meat Sci. 73(4), 559-564 (2006). https://doi. org/10.1016/j.meatsci.2006.02.004

8. J.A. Posthuma, F.D. Rasmussen, G.A. Sullivan, Effects of nitrite source, reducing compounds, and holding time on cured color development in a cured meat model system. LWT 95, 47-50 (2018). https://doi.org/10.1016/j.lwt.2018.04.040

9. W.P. Hammes, Metabolism of nitrate in fermented meats: the characteristic feature of a specific group of fermented foods. Food Microbiol. 29(2), 151-156 (2012). https://doi.org/10.1016/j. fm.2011.06.016

10. J.J. Sindelar, J.C. Cordray, J.G. Sebranek, J.A. Love, D.U. Ahn, Effects of varying levels of vegetable juice powder and incubation time on color residual nitrate and nitrite pigment $\mathrm{pH}$ and trained sensory attributes of ready-to-eat uncured ham. J. Food Sci. 72(6), S388-S395 (2007). https://doi.org/10.111 1/j.1750-3841.2007.00404.x
11. J. Sang-Keun, C.J. Seok, Y. Han-Sul, P. Tae-Seon, Y. Dong-Gyun, Natural curing agents as nitrite alternatives and their effects on the physicochemical, microbiological properties and sensory evaluation of sausages during storage. Meat Sci. 146, 34-40 (2018). https://doi.org/10.1016/j.meatsci.2018.07.032

12. J. Gøtterup, K. Olsen, S. KnØ, K. chel, Tjener, L.H. Stahnke, , Colour formation in fermented sausages by meat-associated staphylococci with different nitrite- and nitrate-reductase activities. Meat Sci. 78(4), 492-501 (2008). https://doi.org/10.1016/j. meatsci.2007.07.023

13. L.D. Frédéric Ravyts, Bacterial diversity and functionalities in food fermentations. Eng. Life Sci. 12(4), 356-367 (2012). https ://doi.org/10.1002/elsc.201100119

14. M.S. Mainar, F. Leroy, Process-driven bacterial community dynamics are key to cured meat colour formation by coagulasenegative staphylococci via nitrate reductase or nitric oxide synthase activities. Int. J. Food Microbiol. 212, 60-66 (2015). https ://doi.org/10.1016/j.ijfoodmicro.2015.03.009

15. R. Bosse, M. Gibis, H. Schmidt, J. Weiss, Nitrate reductase activity of Staphylococcus carnosus affecting the color formation in cured raw ham. Food Res. Int. 85, 113-120 (2016). https://doi. org/10.1016/j.foodres.2016.04.021

16. S.P. Suman, P. Joseph, Chemical and physical characteristics of meat/color and pigment. Encyclopedia Meat Sci. 36(3), 244-251 (2014). https://doi.org/10.1016/B978-0-12-384731-7.00084-2

17. I. Essid, H.B. Ismail, S.B.H. Ahmed, R. Ghedamsi, M. Hassouna, Characterization and technological properties of Staphylococcus xylosus strains isolated from a Tunisian traditional salted meat. Meat Sci. 77(2), 204-212 (2007). https://doi.org/10.1016/j.meats ci.2007.03.003

18. M.C. Miralles, J. Flores, G. Perez-Martinez, Biochemical tests for the selection of Staphylococcusstrains as potential meat starter cultures. Food Microbiol. 13(3), 227-236 (1996). https://doi. org/10.1006/fmic.1996.0028

19. J.D. Brenner, R.N. Krieg, R.J. Staley, Bergey's Manual of Systematic Bacteriology (Springer, Berlin, Germany, 2005).

20. M.Y. Cai, X.Z. Dong, Common Bacterial System Identification Manual. Common Bacterial System Identification Manual (Science Press, Beijing, China, 2001).

21. A. Ameri, M. Shakibaie, M. Soleimani-Kermani, M.A. Faramarzi, H. Forootanfar, Overproduction of thermoalkalophilic lipase secreted by Bacillus atrophaeus FSHM2 using UV-induced mutagenesis and statistical optimization of medium components. Prep. Biochem. Biotechnol. 49(2), 184-191 (2019). https://doi. org/10.1080/10826068.2019.1566148

22. C.P. Durthi, M. Pola, S.B. Rajulapati, A.K. Kola, Screening, optimization of culture conditions and scale-up for production of the L-Glutaminase by novel isolated Bacillus sps. mutant endophyte using response surface methodology. Biocatal. Agric. Biotechnol. 18, 101077 (2019). https://doi.org/10.1016/j.bcab.2019.101077

23. A. Sílvia Moreira, M.E. Pintado, J.A. Saraiva, Optimization of high hydrostatic pressure assisted extraction of stinging nettle leaves using response surface methodology experimental design. J. Food Meas. Charact. 14(12), 2773-2780 (2020). https://doi. org/10.1007/s11694-020-00522-0

24. I. Essid, M. Hassouna, Effect of inoculation of selected Staphylococcus xylosus and Lactobacillus plantarum strains on biochemical, microbiological and textural characteristics of a Tunisian dry fermented sausage. Food Control 32(2), 707-714 (2013). https:// doi.org/10.1016/j.foodcont.2013.02.003

25. R. Greta, B. Annika, P. Johanna, K. Guenter, Effects of parsley extract powder as an alternative for the direct addition of sodium nitrite in the production of mortadella-type sausages - Impact on microbiological, physicochemical and sensory aspects. Meat Sci. 131, 166-175 (2017). https://doi.org/10.1016/j.meats ci.2017.05.007 
26. H. Neubauer, F. Götz, Physiology and interaction of nitrate and nitrite reduction in Staphylococcus carnosus. J. Bacteriol. (1996). https://doi.org/10.1111/j.1365-2672.1996.tb03243.x

27. I.M. Chernukha, M.Y. Minaev, K.A. Kurbakov, D.S. Bataeva, Detection and identification of S. Carnosus in starter cultures using real time PCR and subsequent HRM analysis of amplification products. Procedia Food Sci. (2015). https://doi. org/10.1016/j.profoo.2015.09.010

28. H. Li, L. Zhang, H. Chen, M. Zhang, J. Huang, L. Zhang, D. Wang, Improving NAG production of bacillus amyloliquefaciens by ultraviolet-plasma composite mutagenesis. Food Res. Develop. 039(012), 172-176 (2018)

29. V. Eisinaitè, L. Tamkutè, R. Vinauskienè, D. Leskauskaitè, Freeze-dried celery as an indirect source of nitrate in cold-smoked sausages: effect on safety and color formation. LWT 129, 109586 (2020). https://doi.org/10.1016/j.1wt.2020.109586

30. A.M. Abdel-Aty, R.I. Bassuiny, A.Z. Barakat, S.A. Mohamed, Upgrading the phenolic content, antioxidant and antimicrobial activities of garden cress seeds using solid-state fermentation by Trichoderma reesei. J. Appl. Microbiol. 127(5), 1454-1467 (2019). https://doi.org/10.1111/jam.14394

31. F.O. Ugwele, C.S. Aninwede, T.O. Chime, O. Asadu Christian, $\mathrm{S}$. Ike Innocent, Application of response surface methodology in optimizing the process conditions for the regeneration of used mobil oil using different kinds of acids. Heliyon (2020). https:// doi.org/10.1016/j.heliyon.2020.e05062

32. D.S.C.C. Eduardo, G.D. Funck, D.S.D. Guilherme, L. Haubert, D.L.M. Juliana, I.S. Kroning, Characterization of Staphylococcus xylosus LQ3 and its application in dried cured sausage. LWTFood Sci. Technol. 86, 538-543 (2017). https://doi.org/10.1016/j. lwt.2017.08.045

33. J.G. Sebranek, J.N. Bacus, Cured meat products without direct addition of nitrate or nitrite: what are the issues? Meat Sci. 77(1), 136-147 (2007). https://doi.org/10.1016/j.meatsci.2007.03.025

Publisher's Note Springer Nature remains neutral with regard to jurisdictional claims in published maps and institutional affiliations. 